\title{
Potential new genes for resistance to Mycosphaerella graminicola identified in Triticum aestivum $\times$ Lophopyrum elongatum disomic substitution lines
}

\author{
Joseph M. Anderson • Dennis L. Bucholtz • \\ Nagesh Sardesai • Judith B. Santini • Gábor Gyulai • \\ Christie E. Williams • Stephen B. Goodwin
}

Received: 28 July 2009/ Accepted: 12 October 2009/Published online: 29 October 2009

(C) US Government 2009

\begin{abstract}
Lophopyrum species carry many desirable agronomic traits, including disease resistance, which can be transferred to wheat by interspecific hybridization. To identify potentially new genes for disease and insect resistance carried by individual Lophopyrum chromosomes, 19 of 21 possible wheat cultivar Chinese Spring $\times$ Lophopyrum elongatum disomic substitution lines were tested for resistance to barley yellow dwarf
\end{abstract}

Names are necessary to report factually on available data. However, the USDA neither guarantees nor warrants the standard of the product, and the use of the name implies no approval of the product to the exclusion of others that also may be suitable.

J. M. Anderson - D. L. Bucholtz - C. E. Williams ·

S. B. Goodwin ( $\square)$

Crop Production and Pest Control Research Unit, U. S.

Department of Agriculture-Agricultural Research Service,

Purdue University, 915 West State Street, West Lafayette,

IN 47907-2054, USA

e-mail: Steve.Goodwin@ARS.USDA.gov;

sgoodwin@purdue.edu

N. Sardesai

Department of Entomology, Purdue University, 901 West

State St., West Lafayette, IN 47907-2089, USA

J. B. Santini

Department of Agronomy, Purdue University, 915 West

State St., West Lafayette, IN 47907-2054, USA

G. Gyulai

Institute of Genetics and Biotechnology, HAS-SIU,

Saint Stephanus University, Gödöllő H-2103, Hungary virus (BYDV), cereal yellow dwarf virus (CYDV), the Hessian fly Mayetiola destructor, and the fungal pathogens Blumeria graminis and Mycosphaerella graminicola (asexual stage: Septoria tritici). Low resistance to BYDV occurred in some of the disomic substitution lines, but viral titers were significantly higher than those of two Lophopyrum species tested. This suggested that genes on more than one Lophopyrum chromosome are required for complete resistance to this virus. A potentially new gene for resistance to CYDV was detected on wheatgrass chromosome 3E. All of the substitution lines were susceptible to Mayetiola destructor and one strain of B. graminis. Disomic substitution lines containing wheatgrass chromosomes $1 \mathrm{E}$ and $6 \mathrm{E}$ were significantly more resistant to $M$. graminicola compared to Chinese Spring. Although neither chromosome by itself conferred resistance as high as that in the wheatgrass parent, they do appear to contain potentially new genes for resistance against this pathogen that could be useful for future plant-improvement programs.

Keywords Barley yellow dwarf virus - Cereal yellow dwarf virus - Resistance - Septoria tritici blotch - Wheatgrass substitution lines .

Wheat breeding

\section{Introduction}

Species of wheatgrass (genus Lophopyrum, also known as Agropyron, Elytrigia, and Thinopyrum) 
have been crossed to bread wheat (Triticum aestivum) to produce addition and substitution lines for improving tolerance to abiotic and biotic stresses including salinity (Dubcovsky et al. 1994), drought (Farshadfar and Sutka 2003), and several pathogens such as Puccinia triticina (the cause of leaf rust; Dvořák and Knott 1997), P. graminis f. sp. tritici (stem rust; Knott 1984), P. striiformis (stripe or yellow rust; Ma et al. 2000; Zu-Jun and Zheng-Long 2001), Fusarium graminearum (Fusarium head blight or scab; Jauhar and Peterson 2000; Shen et al. 2004), and barley yellow dwarf virus (Sharma et al. 1984; Shukle et al. 1987; Sharma et al. 1989). These studies clearly demonstrate that Lophopyrum species carry many desirable agronomic traits. However, genome compositions within this genus vary widely: L. elongatum is a diploid with genome EE, L. intermedium is a hexaploid $\left(\mathrm{E}_{1} \mathrm{E}_{1} \mathrm{E}_{2} \mathrm{E}_{2} \mathrm{StSt}\right)$, and L. ponticum is a decaploid (EEEEEEEEEE). The use of diverse wheat and wheatgrass accessions has generated a wide array of genotypes in the resulting addition and substitution lines, which has precluded a systematic examination of each wheatgrass chromosome for useful traits.

A nearly complete set of wheatgrass (L. elongatum) disomic substitution lines for homoeologous chromosomes of the hexaploid wheat cultivar Chinese Spring is now available (Dvořák 1980; Dvořák and Chen 1984; Tuleen and Hart 1998). This set of substitution lines provides the means to study the effects of each wheatgrass chromosome in a common genetic background of bread wheat. Since L. elongatum is diploid (genome EE; $2 n=2 x=14$ ) and wheat is hexaploid (genome AABBDD; $2 n=6 x=42$ ), each wheatgrass chromosome is represented by up to three Chinese Spring substitution lines. For example, the $3 \mathrm{E}$ chromosome from wheatgrass was substituted for the $3 \mathrm{~A}$, $3 \mathrm{~B}$, and $3 \mathrm{D}$ chromosomes from wheat. The three individual substitutions for each wheat chromosome should reveal phenotypes contributed by the alien chromosome as well as those lost by deletion of the corresponding wheat chromosome (Forster et al. 1987). This set of lines was used to test for resistance to yellow rust (Ma et al. 2000) and BYDV (McGuire et al. 1995) in field studies, and the line with wheatgrass chromosome 7E substituted for wheat chromosome 7B was used to augment resistance to Fusarium head blight (Shen and Ohm 2006). These analyses confirmed the utility of these lines for enhancing disease resistance in breeding programs.
The purpose of this study was to test wheat, wheatgrass, and the 19 available disomic substitution lines for resistance to numerous pests and pathogens of wheat including the viruses BYDV and CYDV, the insect pest Mayetiola destructor (Hessian fly), and the fungal pathogens Blumeria graminis (the cause of powdery mildew) and Mycosphaerella graminicola (asexual stage Septoria tritici; the cause of septoria tritici blotch). To assist the possible future manipulation of these resistances, these lines also were characterized with molecular markers and some of their physical traits were noted.

\section{Materials and methods}

\section{Plant material}

Seeds of the 19 available wheat $\times$ wheatgrass substitution lines (Dvořák 1980; Dvořák and Chen 1984; Tuleen and Hart 1998) were kindly provided by Dr. Jan Dvořák of the University of California, Davis. These lines were made by substituting each of the seven E-genome chromosomes from wheatgrass for its three homoeologous (A, B, and D genome) chromosomes in wheat cultivar Chinese Spring. All lines are known to contain the euploid number of 42 chromosomes for hexaploid wheat (Dvořák 1980; Dvořák and Chen 1984; Tuleen and Hart 1998) and are named as described by Zhang and Dvořák (1990), in which the wheatgrass (E genome) chromosome is listed, followed by the replaced wheat chromosome in parentheses. Thus, $2 \mathrm{E}(2 \mathrm{~B})$ is the line in which wheatgrass chromosome $2 \mathrm{E}$ is substituted for wheat chromosome 2B. Among the 21 possible disomic substitution lines for hexaploid wheat, all were available except for lines $4 \mathrm{E}(4 \mathrm{~B})$ and $5 \mathrm{E}(5 \mathrm{~A})$. Seed supply was limited for substitution line $1 \mathrm{E}(1 \mathrm{~B})$ so it was not included in all tests. The L. elongatum accession used as the chromosome donor was collected in Tunisia originally (Dvořák and Knott 1974) but was no longer available, so L. elongatum accession 142012 was used as a control in its place. This accession originated in Odessa province of the former Soviet Union (now Ukraine) and was chosen at random from 55 diploid (L. elongatum) and 6 decaploid (L. ponticum) accessions of wheatgrass, all of which were highly resistant to BYDV and CYDV (J. M. Anderson, unpublished). Other controls in all 
tests included $L$. intermedium $\mathrm{cv}$. Oahe (Curtis and Curtis, Inc, Clovis, NM 88101) and wheat cv. Chinese Spring. The former line was used because previous virus inoculation data were available for it and some of its derived addition and substitution lines. Both hexaploid (L. intermedium) and diploid (L. elongatum) wheatgrass species have been used previously as sources of traits for integration into wheat. Therefore, using both as controls should provide an effective surrogate for the missing parent of the disomic substitution lines and also provide a limited indication of the variability for these resistance traits in wheatgrass. Plants of each line were grown in a greenhouse and scored for physical characteristics such as spike appearance, height and days to anthesis. Separate sets of plants were grown for each pathogen analysis and phenotypic data were collected from untreated plants.

\section{BYDV and CYDV}

The BYDV-PAV and CYDV-RPV strains were maintained as a mixed culture in oats (Avena sativa cv. Clintland 64) in a growth chamber at $18^{\circ} \mathrm{C}, 80 \%$ relative humidity, $16-\mathrm{h}$ photoperiod with the aphid vector Rhopalosiphum padi. A mixed infection of both viruses was used because no differences were seen in titer or the timing of virus accumulation between the responses of mixed or single infections in either susceptible wheat lines or in BYDV/ CYDV-resistant wheat lines carrying a related chromosome from Lophopyrum intermedium cv. Oahe (J. M. Anderson, unpublished). Therefore, a mixed infection should be sufficient to reveal the resistant or susceptible phenotype of the substitution lines with the small quantity of seeds that were available. Virus titer was measured as described previously (Anderson et al. 1998). Briefly, seedlings at the two-leaf stage were infested with approximately 5-20 viruliferous aphids per seedling. After a $48-\mathrm{h}$ virus transmission period, the aphids were killed with the insecticide Malathion. Leaf tissue was collected 12 days later for assay by doubleantibody sandwich ELISA with antibodies specific for BYDV-PAV and CYDV-RPV. Leaf tissue from seven to eight plants of each genotype was collected and virus titer in each plant was estimated by ELISA. Each plant was considered as a replicate for statistical analysis.
Hessian fly

Fifteen seeds of each accession, except for the $1 \mathrm{E}(1 \mathrm{~B}), 4 \mathrm{E}(4 \mathrm{~B})$ and $5 \mathrm{E}(5 \mathrm{~A})$ lines for which no seed was available, were planted in each of two $10-\mathrm{cm}$ plastic pots that were replications in a randomized complete block design. The pots were initially placed in a cold chamber at $4^{\circ} \mathrm{C}$ for 1 week to synchronize germination, and then transferred to a growth chamber maintained at $18^{\circ} \mathrm{C}, 85 \%$ humidity, and a $24-\mathrm{h}$ photoperiod. When the seedlings reached the two-leaf stage (7 days post germination), each pot of plants was infested with three newly emerged adult males and females of Hessian fly biotype L, and then covered with a plastic cup. Biotype L, maintained as a purified laboratory stock, is virulent to all known Hessian fly-resistance genes, except for lines containing genes H13 (Ratcliffe et al. 1996), H2l (Seo et al. 2001), H25 (Friebe et al. 1996), H31 (Williams et al. 2003), H32 (Sardesai et al. 2005) and Hdic (Liu et al. 2005). Ten plants from each of the infested pots (total of 20 plants per entry) were selected arbitrarily and scored for resistance 15 days after infestation. However, for five of the substitution lines, 17 to 18 plants rather than 20 were scored due to a lower germination rate or fewer than 20 seeds at planting. Because the results for the two replications were very similar, the data from all plants scored for an entry were combined to obtain the average number of larvae per plant. The lines were considered resistant if $20 \%$ or fewer of the infested plants contained living larvae.

\section{Powdery mildew}

A culture of Blumeria graminis strain 8, kindly provided by Dr. Steven Leath (North Carolina State University), was maintained on the susceptible wheat cultivar Chancellor. Plants of each substitution line plus controls were grown in a growth chamber at $20^{\circ} \mathrm{C}, 80 \%$ relative humidity with a 16 -h photoperiod. Heavily infected leaves of Chancellor were used to inoculate five plants of each line at the 2-leaf stage. Conidia were transferred by gently shaking the infected leaves over the test plants. Ten days after inoculation, the plants were evaluated for the presence or absence of fungal growth and lesions. Plants containing large, sporulating lesions were considered susceptible. 
Septoria tritici blotch

Seeds of each available substitution line, Chinese Spring, wheatgrass cultivars Oahe and 142012 and, in one test, the highly susceptible wheat cultivar Taichung 29, were sown in flats, chilled for 1 week at $4^{\circ} \mathrm{C}$ to break dormancy, then placed in a greenhouse for germination. After germination the flats were placed back in the cold room for 3 weeks to synchronize their development, then were brought back into the greenhouse and the seedlings were allowed to acclimate before transplanting into individual pots. Each plant was considered a replicate and the pots were placed on the greenhouse bench in a completely random design. The entire experiment was replicated three times and the number of plants of each line varied from zero to 16 per experiment, depending on availability and germination of seed.

Plants were inoculated by spraying fully emerged flag leaves with blastospores of isolate T48 (IN95Lafayette-1196-WW 1-4) of Mycosphaerella graminicola. This isolate was obtained from an infected wheat leaf collected in the field in Indiana during 1995 (Adhikari et al. 2003) and has been maintained at $-80^{\circ} \mathrm{C}$ on lyophilized filter-paper stocks. Inoculum was grown in 250-ml flasks containing $100 \mathrm{ml}$ of yeast-sucrose broth; kanamycin sulfate $\left(50 \mu \mathrm{g} \mathrm{ml}^{-1}\right)$ was added to preclude bacterial contamination. Cultures were initiated with $100 \mu \mathrm{l}$ of an actively growing liquid culture and shaken at $150 \mathrm{rpm}$ on a rotary shaker. When the cultures became cloudy (after 3-5 days), the spores were counted with a hemacytometer and diluted with water to $5 \times 10^{7} \mathrm{ml}^{-1}$. Approximately 15-20 drops of Tween 20 (polyoxyethylene sorbitan monolaurate) were added to each batch of inoculum and mixed for $15 \mathrm{~min}$ before inoculation to reduce surface tension. Spore suspensions were sprayed with an atomizer onto plants having fully expanded flag leaves on two successive days. Following inoculation, a humid environment was created to enhance fungal growth by covering the plants for $72 \mathrm{~h}$ with a tent consisting of an inner and outer layer of canvas and clear polyethylene plastic, respectively, and flooding the greenhouse benches. Plants were scored visually for disease severity and pycnidial density once symptoms had developed fully, approximately 24-28 days post inoculation. Disease severity was estimated as the percentage of the leaf surface covered by lesions, and the density of pycnidia within the lesions was estimated on a 0 to 5 scale as described by Adhikari et al. (2003), where $0=$ no pycnidia and $5=$ maximum pycnidia production.

Analysis of variance on arcsin-transformed disease severity and pycnidial density values was conducted using SAS PROC MIXED (SAS Institute Inc. 2004) for each experiment separately, and (when appropriate), by a combined analysis over all three experiments. Results are presented in back-transformed units. Within each experiment, accessions with zero variance (usually those showing no disease that had zero mean values for disease severity and pycnidial density) were removed to avoid biasing the variance estimates and analysis of variance was used on the remaining accessions. If significant effects were identified, each substitution line was compared to Chinese Spring by $t$ tests. Independently, accessions with zero variance values were also compared to Chinese Spring with $t$ tests.

A combined-experiment analysis of variance was conducted for all possible substitution lines. Initially, all accessions present in the three experiments were considered for inclusion. Accessions with large numbers of zero responses were deleted iteratively until the within-experiment error variances were homogeneous. If significant effects were identified, each substitution line was compared to Chinese Spring by $t$ tests.

\section{Microsatellite characterization}

Genomic DNA was isolated from seedling leaf tissue of the wheat cultivars, Lophopyrum accession controls, and substitution lines as described previously (Francki et al. 1997). Wheat microsatellite primers described by Röder et al. (1998) were used to confirm that a wheatgrass chromosome was present in each substitution line. Forty-nine primer pairs, previously mapped to the individual wheat chromosomes, were tested to determine whether they produced wheatgrass-specific bands. Eleven primer pairs that generated wheatgrass-specific polymorphisms were used to analyze the substitution lines. Each reaction contained $40 \mathrm{ng}$ of genomic DNA, 1 unit of Taq DNA polymerase, $200 \mu \mathrm{M}$ of each dNTP, $400 \mathrm{nM}$ of each primer, $2.5 \mathrm{mM} \mathrm{MgCl}_{2}, 10 \mathrm{mM}$ Tris- $\mathrm{HCl} \mathrm{pH} 9.0$, $50 \mathrm{mM} \mathrm{KCl}$ and $0.1 \%$ Triton $\mathrm{X}-100$ in a volume of $25 \mu$ l. The PCR program used was $94^{\circ} \mathrm{C}$ for $3 \mathrm{~min}$ followed by 35 cycles of $94^{\circ} \mathrm{C}$ for $40 \mathrm{~s}, 50$ to $60^{\circ} \mathrm{C}$ depending on the annealing temperature of the 
primers (Röder et al. 1998) for $50 \mathrm{~s}$, and $72^{\circ} \mathrm{C}$ for $1 \mathrm{~min}$, with a final extension of $72^{\circ} \mathrm{C}$ for $4 \mathrm{~min}$. The PCR products were visualized on $3 \%$ agarose gels in $1 \times$ TBE buffer stained with ethidium bromide.

\section{Results}

\section{BYDV/CYDV}

The mixed infections were very efficient. The infection rate was assessed by determining how many of the 18 Chinese Spring plants inoculated were infected: for BYDV-PAV the ELISA optical density (OD) range for individual plants was 0.8-2.0 (no escapes), with a median OD of 1.43 and an average of 1.44; for CYDV-RPV the ELISA OD range was $0.49-1.18$ (no escapes), with a median of 0.97 and an average OD of 0.94 .

ELISA analysis identified statistically significant reductions in the BYDV titer in L. elongatum cv. 142012, L. intermedium cv. Oahe, and the substitution lines $2 \mathrm{E}(2 \mathrm{~B}), 2 \mathrm{E}(2 \mathrm{D}), 3 \mathrm{E}(3 \mathrm{~A})$, and $3 \mathrm{E}(3 \mathrm{~B})$ relative to Chinese Spring (Table 1). The CYDV titer was reduced, relative to Chinese Spring, in all but three of the 19 substitution lines. However, titer was reduced consistently for each substituted wheat chromosome only for the lines involving wheatgrass chromosomes $2 \mathrm{E}, 3 \mathrm{E}, 6 \mathrm{E}$ and $7 \mathrm{E}$. The strongest resistance against CYDV was for lines $1 \mathrm{E}(1 \mathrm{~B})$, $2 \mathrm{E}(2 \mathrm{~B}), 2 \mathrm{E}(2 \mathrm{D})$ and $3 \mathrm{E}(3 \mathrm{~B})$.

All of the substitution lines had significantly higher BYDV titer compared to the two Lophopyrum accessions tested (Table 1). Fifteen of the 19 substitution lines also had CYDV titers significantly higher than the two resistant Lophopyrum controls. Throughout this study, the alien chromosome was generally not considered to contribute to resistance to a pathogen/ pest unless all three of the substitution lines followed the same resistance trend. However, it is possible that if one of the three substitutions increased resistance, this could be interpreted that the substituted T. aestivum chromosome contained a locus causing increased susceptibility.

Hessian fly

All of the lines tested were susceptible to Hessian fly biotype $\mathrm{L}$ except for $L$. intermedium $\mathrm{cv}$. Oahe
Table 1 Virus titers estimated by ELISA and susceptibility to Hessian fly of 19 wheat cultivar Chinese Spring $\times$ Lophopyrum elongatum disomic substitution lines and controls

\begin{tabular}{|c|c|c|c|}
\hline Accession & $\begin{array}{l}\text { BYDV } \\
\text { (PAV) }\end{array}$ & $\begin{array}{l}\text { CYDV } \\
\text { (RPV) }\end{array}$ & $\begin{array}{l}\text { Hessian } \\
\text { fly }\end{array}$ \\
\hline $1 \mathrm{E}(1 \mathrm{~A})$ & 1.33 & $0.53 *$ & $\mathrm{~S}^{\mathrm{a}}$ \\
\hline $1 \mathrm{E}(1 \mathrm{~B})$ & $1.23^{\mathrm{b}}$ & $0.11^{* \mathrm{~b}}$ & $\mathrm{nt}^{\mathrm{c}}$ \\
\hline $1 E(1 D)$ & 1.37 & 0.83 & S \\
\hline $2 \mathrm{E}(2 \mathrm{~A})$ & 1.22 & $0.35 *$ & $\mathrm{~S}$ \\
\hline $2 \mathrm{E}(2 \mathrm{~B})$ & $0.72 *$ & $0.18 *$ & $\mathrm{~S}$ \\
\hline $2 \mathrm{E}(2 \mathrm{D})$ & $0.69 *$ & $0.18 *$ & $\mathrm{~S}$ \\
\hline $3 \mathrm{E}(3 \mathrm{~A})$ & $1.15^{*}$ & $0.40 *$ & $\mathrm{~S}$ \\
\hline $3 \mathrm{E}(3 \mathrm{~B})$ & $1.02 *$ & $0.10^{*}$ & $\mathrm{~S}$ \\
\hline $3 \mathrm{E}(3 \mathrm{D})$ & 1.58 & $0.30 *$ & $\mathrm{~S}$ \\
\hline $4 \mathrm{E}(4 \mathrm{~A})$ & 1.21 & $0.60 *$ & $\mathrm{~S}$ \\
\hline $4 \mathrm{E}(4 \mathrm{D})$ & 1.72 & 0.83 & $\mathrm{~S}$ \\
\hline $5 \mathrm{E}(5 \mathrm{~B})$ & 1.83 & 0.85 & $\mathrm{~S}$ \\
\hline $5 \mathrm{E}(5 \mathrm{D})$ & 1.58 & $0.64 *$ & $\mathrm{~S}$ \\
\hline $6 \mathrm{E}(6 \mathrm{~A})$ & 1.25 & $0.62 *$ & $\mathrm{~S}$ \\
\hline $6 \mathrm{E}(6 \mathrm{~B})$ & 1.64 & $0.37 *$ & $\mathrm{~S}$ \\
\hline $6 \mathrm{E}(6 \mathrm{D})$ & 1.74 & $0.52 *$ & $\mathrm{~S}$ \\
\hline 7E(7A) & 1.60 & $0.63 *$ & $\mathrm{~S}$ \\
\hline $7 \mathrm{E}(7 \mathrm{~B})$ & 1.72 & $0.66 *$ & $\mathrm{~S}$ \\
\hline 7E(7D) & 1.68 & $0.54 *$ & $\mathrm{~S}$ \\
\hline Chinese Spring & 1.44 & 0.94 & $\mathrm{~S}$ \\
\hline L. intermedium Oahe & $0.00 *$ & $0.03 *$ & $\mathrm{R}$ \\
\hline L. elongatum 142012 & $0.027 *$ & $0.03 *$ & $\mathrm{~S}$ \\
\hline $\operatorname{LSD}(P=0.05)$ & 0.24 & 0.17 & N/A \\
\hline
\end{tabular}

* Significantly different from Chinese Spring at $P<0.05$

a $S=$ susceptible and $R=$ resistant based on the presence of live larvae

b Only one plant tested due to limited availability of seed

c Not tested due to limited availability of seed

(Table 1). The susceptible plants showed the characteristic stunting phenotype and harbored an average of 3 to 16 living larvae. Most of the larvae were in the green gut stage of late 2 nd instar, indicating that they developed at the normal rate. The $L$. intermedium accession was considered resistant because the seedlings were not stunted and they contained only dead, red first-instar larvae.

Powdery mildew

All of the substitution lines and the wheat and wheatgrass controls were equally susceptible to 
B. graminis strain 8 under the controlled environmental conditions and high inoculum pressure in the growth chamber (data not shown).

\section{Septoria tritici blotch}

Disease severities and pycnidial densities on leaves inoculated with $M$. graminicola varied depending on the chromosome substitution. Wheatgrass cultivars Oahe (L. intermedium) and 142012 (L. elongatum) were immune to $M$. graminicola so had significantly lower disease severities and pycnidial densities compared to Chinese Spring in each experiment (Table 2). Disease severities of several disomic substitution lines also were significantly lower than those for Chinese Spring in all three experiments, particularly when wheatgrass chromosome $1 \mathrm{E}$ was substituted for wheat chromosomes $1 \mathrm{~A}$ and $1 \mathrm{D}$, and when wheatgrass chromosome $6 \mathrm{E}$ was substituted for wheat chromosome 6B. Disease severities were significantly lower than those for Chinese Spring in two of the three experiments when wheatgrass chromosome $5 \mathrm{E}$ was substituted for wheat chromosome $5 \mathrm{D}$, when wheatgrass chromosome 6E was substituted for wheat chromosomes $6 \mathrm{~A}$ and $6 \mathrm{D}$, and when wheatgrass chromosome 7E was substituted for wheat chromosome 7D (Table 2). Pycnidial densities were significantly lower than those for Chinese Spring in two of the three experiments for substitution lines $1 \mathrm{E}(1 \mathrm{D}), 6 \mathrm{E}(6 \mathrm{~A})$ and $6 \mathrm{E}(6 \mathrm{D})$. Wheatgrass chromosomes $2 \mathrm{E}, 3 \mathrm{E}$ and $7 \mathrm{E}$ gave significantly lower disease severities and/or pycnidial densities in at least one substitution line in a single experiment only. In contrast, disease severities and/or pycnidial densities were significantly higher than those for Chinese Spring in one or more experiments for lines $3 \mathrm{E}(3 \mathrm{~A}), 4 \mathrm{E}(4 \mathrm{D}), 5 \mathrm{E}(5 \mathrm{~B})$ and the highly susceptible wheat cultivar Taichung 29 (Table 2).

The accession line effect was not significant for disease severity in the combined analysis (Table 2). However, five of the six most consistently resistant lines had to be excluded from this analysis due to heterogeneous variances. Substitution lines 1E(1A), $1 \mathrm{E}(1 \mathrm{D})$ and $6 \mathrm{E}(6 \mathrm{D})$ had significantly lower pycnidial densities than did Chinese Spring in the combined analysis (Table 2). The three other lines with the most consistently lower pycnidial densities in the individual experiments also had to be excluded from this analysis due to heterogeneity of variances.
Microsatellite characterization

Among forty-nine wheat microsatellite markers tested on the disomic substitution lines, four yielded banding patterns that differed from the Chinese Spring control (Fig. 1). Together, these four markers reconfirmed $\mathrm{E}$ chromosome substitutions in nine of the disomic substitution lines. The absence of wheat chromosome $1 \mathrm{~A}$ was confirmed by the presence of the wheat allele of Xgwm666 in all samples except for $1 \mathrm{E}(1 \mathrm{~A})$. Because this marker did not amplify in the line $1 \mathrm{E}(1 \mathrm{~A})$ or $L$. elongatum samples, indicating no corresponding locus in wheatgrass, the presence of the $1 \mathrm{E}$ chromosome was inferred by chromosome analyses (Dvořák 1980; Dvořák and Chen 1984; Tuleen and Hart 1998). Locus Xgwm382 displayed two bands in the Chinese Spring control and had a third band in the $2 \mathrm{E}(2 \mathrm{~A}, 2 \mathrm{~B}, 2 \mathrm{D})$ wheatgrass lines. The higher molecular weight wheat band is missing from sample 2E(2D) and the lower molecular weight band is missing from $2 \mathrm{E}(2 \mathrm{~A})$, confirming the absence of these chromosomes. This marker is not polymorphic for chromosome $2 \mathrm{~B}$, but the chromosome number for the 2E(2B) line is 42 (Dvořák and Chen 1984), indicating the absence of 2B. Marker Xgwm190 corresponds to loci on homeologous groups 5 and 7. One band is present in the Chinese Spring sample, whereas wheatgrass samples yield a band of the same molecular weight as well as a larger and smaller band. The common band is present in all disomic substitution line samples. However, the larger band is present in the $5 \mathrm{E}(5 \mathrm{~B}$ and $5 \mathrm{D})$ samples and the smaller band is present in the 7E(7A, 7B, 7D) samples. Locus Xgwm111 yields two bands in the Chinese Spring sample, the smaller of which is also present in wheatgrass. However, the larger band is not present in the 7E(7D) sample indicating the absence of 7D.

\section{Phenotypic characterization}

The phenotypic analysis identified two lines with spike characteristics different from Chinese Spring. The $5 \mathrm{E}(5 \mathrm{D})$ line had a long spike with an average of 26 spikelets compared to 16 for Chinese Spring, and the $6 \mathrm{E}(6 \mathrm{~B})$ spike was awned (Fig. 2). Because these two characteristics did not occur in the $5 \mathrm{E}(5 \mathrm{~B})$, $6 \mathrm{E}(6 \mathrm{~A})$, or $6 \mathrm{E}(6 \mathrm{D})$ lines, they must have arisen from the loss of the wheat chromosome and not the addition of the L. elongatum chromosome. In addition 
Table 2 Response of wheat cultivar Chinese Spring and 19 wheat $\times$ Lophopyrum elongatum disomic substitution lines to inoculation with Mycosphaerella graminicola isolate T48 over three experiments ${ }^{\mathrm{a}}$

\begin{tabular}{|c|c|c|c|c|c|c|c|c|}
\hline \multirow[t]{2}{*}{ Accession $^{c}$} & \multicolumn{2}{|c|}{ Experiment 1} & \multicolumn{2}{|c|}{ Experiment 2} & \multicolumn{2}{|c|}{ Experiment 3} & \multicolumn{2}{|c|}{ Combined $^{\text {b }}$} \\
\hline & Severity & Pycnidia & Severity & Pycnidia & Severity & Pycnidia & Severity & Pycnidia \\
\hline $1 \mathrm{E}(1 \mathrm{~A})$ & $2.4^{*}$ & $0.1^{*}$ & $0.8^{* *}$ & $1.3^{* *}$ & $0.0^{\dagger \dagger}$ & $0.0^{\dagger \dagger}$ & $\mathrm{N} / \mathrm{A}^{\mathrm{d}}$ & $0.3 * *$ \\
\hline $1 \mathrm{E}(1 \mathrm{~B})$ & $-{ }^{\mathrm{e}}$ & - & $8.7^{*}$ & 4.0 & 6.4 & 3.0 & N/A & N/A \\
\hline $1 \mathrm{E}(1 \mathrm{D})$ & $10 *{ }^{\mathrm{f}}$ & 1.9 & $6.9^{*}$ & $0.8^{* *}$ & $0.6^{*}$ & $0.0^{\dagger \dagger}$ & 5.2 & $0.6^{*}$ \\
\hline $2 \mathrm{E}(2 \mathrm{~A})$ & 21.4 & 2.7 & $7.9^{*}$ & 4.6 & 11.7 & 3.4 & 14.0 & 3.9 \\
\hline $2 \mathrm{E}(2 \mathrm{~B})$ & 10.8 & 2.1 & $9.6^{*}$ & 2.7 & - & - & N/A & N/A \\
\hline $2 \mathrm{E}(2 \mathrm{D})$ & 16.6 & 2.6 & 37.4 & 4.7 & 20.7 & 3.8 & 25.6 & 3.9 \\
\hline $3 \mathrm{E}(3 \mathrm{~A})$ & $81.0 *$ & 4.7 & 28.8 & 4.9 & 19.4 & 3.2 & 40.5 & 4.5 \\
\hline $3 \mathrm{E}(3 \mathrm{~B})$ & 23.2 & 3.4 & 14.0 & 4.9 & 16.6 & 3.1 & 19.7 & 4.1 \\
\hline $3 \mathrm{E}(3 \mathrm{D})$ & 19.3 & 2.9 & 17.0 & 4.0 & $1.1 * *$ & $0.7 *$ & 10.4 & 2.5 \\
\hline $4 \mathrm{E}(4 \mathrm{~A})$ & 23.2 & 2.8 & $50.1 *$ & 4.8 & 10.6 & 2.1 & 26.5 & 3.5 \\
\hline $4 \mathrm{E}(4 \mathrm{D})$ & $62.9 *$ & $4.9^{*}$ & $53.2 *$ & 5.0 & 3.7 & 1.7 & 36.1 & 4.3 \\
\hline $5 \mathrm{E}(5 \mathrm{~B})$ & $66.3 *$ & $4.6^{*}$ & $49.0 *$ & 4.3 & 13.3 & 2.8 & 40.9 & 4.0 \\
\hline $5 \mathrm{E}(5 \mathrm{D})$ & 51.0 & 4.0 & $8.6^{*}$ & 3.3 & $0.0^{\dagger \dagger}$ & $\mathbf{0 . 0} 0^{\dagger \dagger}$ & N/A & 2.2 \\
\hline $6 \mathrm{E}(6 \mathrm{~A})$ & 46.1 & 3.6 & $0.4^{* *}$ & $\mathbf{0 . 0} 0^{\dagger \dagger}$ & $\mathbf{0 . 0 ^ { \dagger \dagger }}$ & $\mathbf{0 . 0} 0^{\dagger \dagger}$ & N/A & N/A \\
\hline $6 \mathrm{E}(6 \mathrm{~B})$ & $10 *{ }^{\mathrm{f}}$ & $1 *^{\mathrm{f}}$ & $0.5^{* *}$ & $0.9 * *$ & $0.0^{\dagger \dagger}$ & $\mathbf{0 . 0} 0^{\dagger \dagger}$ & N/A & N/A \\
\hline $6 \mathrm{E}(6 \mathrm{D})$ & 24.3 & 3.0 & $0.5^{* *}$ & $0.4^{* *}$ & $0.0^{\dagger \dagger}$ & $\mathbf{0 . 0} 0^{\dagger \dagger}$ & N/A & $0.7^{*}$ \\
\hline $7 \mathrm{E}(7 \mathrm{~A})$ & 51.6 & 4.6 & 34.0 & 4.6 & $0.9 * *$ & $0.9 *$ & 22.1 & 3.4 \\
\hline $7 \mathrm{E}(7 \mathrm{~B})$ & 42.7 & 3.9 & 41.4 & 4.6 & $1.0 * *$ & $1.1^{*}$ & 22.6 & 3.3 \\
\hline $7 \mathrm{E}(7 \mathrm{D})$ & 56.2 & $4.6^{*}$ & $11.4^{*}$ & 4.3 & $0.3^{* *}$ & $0.2^{* *}$ & 16.0 & 3.0 \\
\hline Chinese Spring & 30.3 & 2.9 & 27.3 & 4.5 & 14.3 & 3.0 & 24.0 & 3.7 \\
\hline L. intermedium Oahe & $0.0^{\dagger \dagger}$ & $\mathbf{0 . 0} 0^{\dagger \dagger}$ & $0.0^{\dagger \dagger}$ & $0.0^{\dagger \dagger}$ & $0.0^{\dagger \dagger}$ & $0.0^{\dagger \dagger}$ & N/A & N/A \\
\hline L. elongatum 142012 & $\mathbf{0 . 0 ^ { \dagger \dagger }}$ & $0.0^{\dagger \dagger}$ & $0.0^{\dagger \dagger}$ & $0.0^{\dagger \dagger}$ & - & - & N/A & N/A \\
\hline Taichung 29 & - & - & - & - & $39.1 *$ & $4.6^{*}$ & N/A & N/A \\
\hline
\end{tabular}

* Significantly different from Chinese Spring at $P<0.05$

** Significantly different from Chinese Spring at $P<0.0001$

† These values had a mean and variance of zero, so could not be included in the analysis of variance. However, $t$ tests indicated that Chinese Spring was significantly different from zero at $P<0.0001$. Therefore, all of these lines had significantly less disease than Chinese Spring

a All disease severities and pycnidial densities that are significantly less than those for Chinese Spring in the individual or combined experiments are indicated in bold. Experiments 1, 2, and 3 were performed during the spring of 2001, fall of 2001 and fall of 2004 , respectively

b Analyzed over all three experiments

${ }^{c}$ For wheatgrass substitution lines, the wheatgrass (E genome) is indicated first, followed by the deleted wheat chromosome in parentheses. Chinese Spring is the recipient wheat cultivar, Taichung 29 is a highly susceptible cultivar of bread wheat, Oahe and 142012 are accessions of wheatgrass species included for comparison

d Not applicable. Variances among experiments were not homogeneous when these lines were considered, so they could not be included in the combined experiments analysis

e Not tested due to lack of availability or poor germination of seeds

f Only one observation was available so there was no variance; could not be included in the analysis of variance but were significantly different from Chinese Spring according to $t$ tests at $P<0.05$

to the long spike, the $5 \mathrm{E}(5 \mathrm{D})$ line was the tallest at approximately $1 \mathrm{~m}$ tall, at least $30 \%$ taller than most of the other lines and almost twice the height of
Chinese Spring (Table 3). The days to anthesis varied greatly among the substitution lines. Lines $1 \mathrm{E}(1 \mathrm{~A})$, $3 \mathrm{E}(3 \mathrm{~A}, 3 \mathrm{~B}, 3 \mathrm{D}), 4 \mathrm{E}(4 \mathrm{~A}), 5 \mathrm{E}(5 \mathrm{~B})$ and $6 \mathrm{E}(6 \mathrm{~A}, 6 \mathrm{~B}, 6 \mathrm{D})$ 
Fig. 1 Agarose gel analysis of four microsatellite markers that identify DNA

polymorphisms in disomic wheat $\times$ wheatgrass substitution lines. The lane designations indicate the missing wheat

chromosome. CS: wheat cultivar Chinese Spring; L: Lophopyrum elongatum. Approximate sizes of the major bands are indicated by arrows on the right

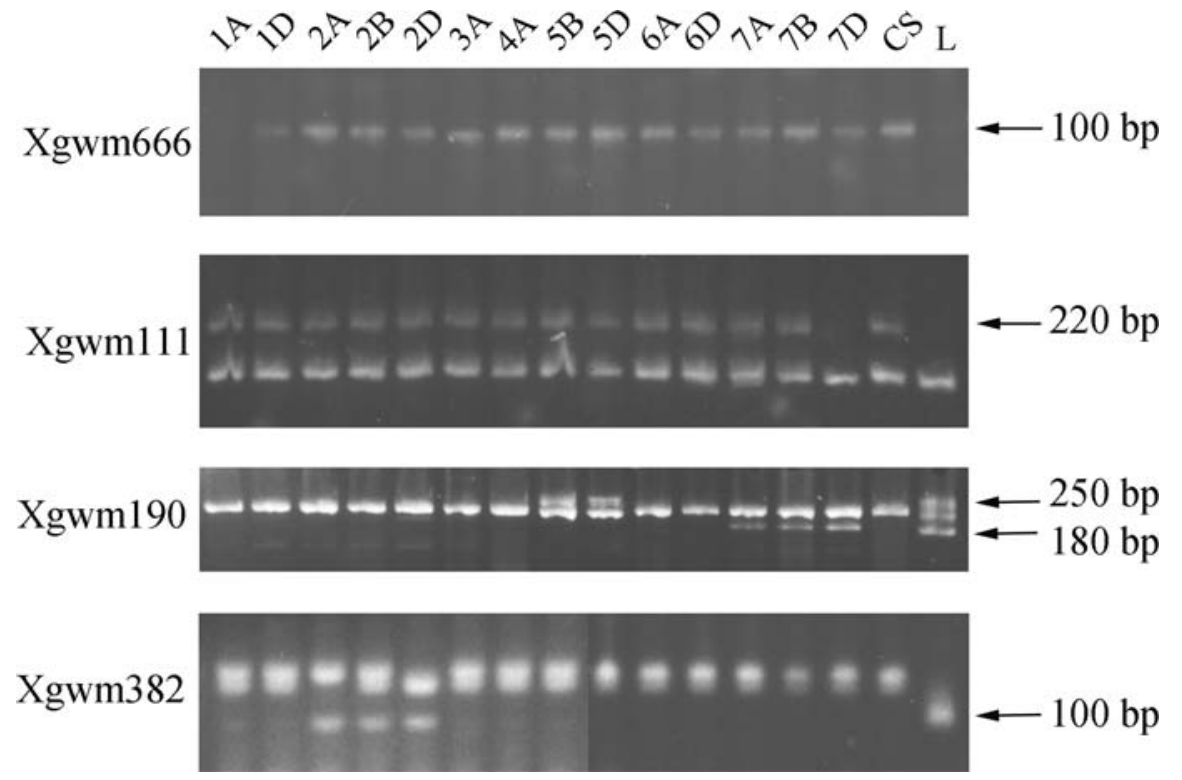

$\mathrm{Xgwm} 382$

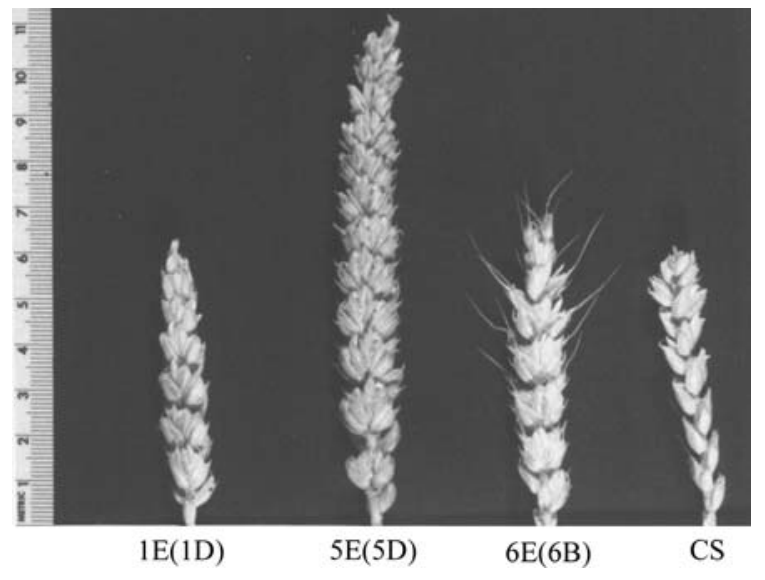

Fig. 2 Spike characteristics of wheat cultivar Chinese Spring and selected wheatgrass disomic substitution lines. The Lophopyrum elongatum chromosome is indicated first with the substituted wheat chromosome in parentheses

were all earlier, with $6 \mathrm{E}(6 \mathrm{~B})$ the earliest, and $5 \mathrm{E}(5 \mathrm{D})$ the latest compared to Chinese Spring (Table 3). The three 7E substitution lines and both Lophopyrum species had purple coleoptiles. Forster et al. (1987) has shown that this coleoptile color locus is also present on the alien group 7 chromosome in the wheat $\times$ L. intermedium addition line L1. The purple coleoptile genes $P c 1, P c 2$, and $P c 3$, which have been mapped to wheat chromosomes $7 \mathrm{~A}, 7 \mathrm{~B}$, and $7 \mathrm{D}$, respectively (McIntosh et al. 1998), are not present in
Chinese Spring. The 7E chromosome appears to carry the purple allele at the corresponding locus.

\section{Discussion}

Introgression of alien genes has been an important tool for improving quality and disease resistance in wheat. In particular, species of wheatgrass (genus Thinopyrum) have been shown to contain useful genes for resistance to abiotic stresses (Dubcovsky et al. 1994; Farshadfar and Sutka 2003) and to several diseases including rusts (Knott 1984; Dvořák and Knott 1997; Ma et al. 2000; Zu-Jun and Zheng-Long 2001), Fusarium head blight (Jauhar and Peterson 2000; Shen et al. 2004) and yellow dwarf (Sharma et al. 1984; Shukle et al. 1987; Sharma et al. 1989). This study was conducted to test whether additional genes for resistance to pests and diseases could be identified on specific L. elongatum chromosomes. The results identified potential new genes for resistance to Septoria tritici blotch (caused by Mycosphaerella graminicola) and CYDV and also confirmed resistances to BYDV that were identified previously (McGuire et al. 1995).

Substitution lines containing wheatgrass chromosome $6 \mathrm{E}$ had significantly lower disease severities and pycnidial densities compared to Chinese Spring, demonstrating that this chromosome carries very 
Table 3 Phenotypic and molecular characteristics of wheat cultivar Chinese Spring and 19 wheat $\times$ Lophopyrum elongatum substitution lines

\begin{tabular}{|c|c|c|c|}
\hline Accession & $\begin{array}{l}\text { Plant height } \\
(\mathrm{cm})\end{array}$ & $\begin{array}{l}\text { Anthesis relative } \\
\text { to CS (days) }\end{array}$ & $\begin{array}{l}\text { Spikelets } \\
\text { per spike }\end{array}$ \\
\hline $1 \mathrm{E}(1 \mathrm{~A})$ & 70 & -1.4 & 19 \\
\hline $1 \mathrm{E}(1 \mathrm{~B})$ & 60 & 6.7 & 16 \\
\hline $1 \mathrm{E}(1 \mathrm{D})$ & 55 & 4.7 & 17 \\
\hline $2 \mathrm{E}(2 \mathrm{~A})$ & 45 & 0.9 & 14 \\
\hline $2 \mathrm{E}(2 \mathrm{~B})$ & 66 & 11.8 & 13 \\
\hline $2 \mathrm{E}(2 \mathrm{D})$ & 53 & 13.1 & 15 \\
\hline $3 \mathrm{E}(3 \mathrm{~A})$ & 73 & -4.2 & 12 \\
\hline $3 \mathrm{E}(3 \mathrm{~B})$ & 60 & -4.4 & 16 \\
\hline $3 \mathrm{E}(3 \mathrm{D})$ & 65 & -3.6 & 17 \\
\hline $4 \mathrm{E}(4 \mathrm{~A})$ & 68 & -5.2 & 15 \\
\hline $4 \mathrm{E}(4 \mathrm{D})$ & 73 & 0.2 & 19 \\
\hline $5 \mathrm{E}(5 \mathrm{~B})$ & 90 & -5.3 & 16 \\
\hline $5 \mathrm{E}(5 \mathrm{D})$ & 103 & 20.9 & 26 \\
\hline $6 \mathrm{E}(6 \mathrm{~A})$ & 68 & -2.7 & 14 \\
\hline $6 \mathrm{E}(6 \mathrm{~B})$ & 65 & -6.0 & 17 \\
\hline $6 \mathrm{E}(6 \mathrm{D})$ & 69 & -4.0 & 18 \\
\hline $7 \mathrm{E}(7 \mathrm{~A})$ & 62 & 6.2 & 14 \\
\hline $7 \mathrm{E}(7 \mathrm{~B})$ & 68 & 9.7 & 15 \\
\hline 7E(7D) & 65 & 0.9 & 17 \\
\hline Chinese Spring & 55 & 0.0 & 16 \\
\hline $\operatorname{LSD}(P=0.05)$ & 15 & 2.5 & 2.4 \\
\hline
\end{tabular}

${ }^{a}$ Days to anthesis relative to Chinese Spring (CS): negative and positive numbers indicate that anthesis occurred prior to and after that of CS, respectively

effective resistance against Septoria tritici blotch (STB). Disease reduction in these lines was not as dramatic during Experiment 1, but this may have been due to earlier senescence of these lines and an infestation of thrips that complicated disease scoring. Resistance of these lines was very consistent during Experiments 2 and 3. Good resistance also was contributed by wheatgrass chromosome $1 \mathrm{E}$ in all three experiments when it was substituted for wheat chromosomes 1A and 1D. The 1E(1B) substitution line had reduced disease, but it was not always significantly less than that in Chinese Spring. This could mean that Chinese Spring contains a small QTL for resistance to STB on this chromosome. However, this hypothesis must be tested by additional experimentation.

Although wheatgrass chromosomes $1 \mathrm{E}$ and $6 \mathrm{E}$ appear to contain genes that provide good resistance to STB, the disomic substitution lines carrying these chromosomes were not immune, except for the $6 \mathrm{E}$ substitution lines in Experiment 3 when overall disease was lower. The results for Experiment 3 may be anomalous due to the lower disease pressure in that test. Therefore, neither chromosome by itself contained the full complement of resistance possessed by the wheatgrass accessions, which were immune to M. graminicola in all of our tests. We do not know the resistance of the wheatgrass donor parent, but presumably it will be similar to the two wheatgrass accessions tested. These experiments indicate that the non-host resistance of L. elongatum most likely involves at least two genes and possibly many more. Combining genes from L. elongatum chromosomes $1 \mathrm{E}$ and $6 \mathrm{E}$ together may reconstitute the high level of STB resistance presumed to be present in the wheatgrass parent, but this remains to be tested.

Among the 13 genes for resistance to STB that have been mapped and published so far (Goodwin 2007; Chartrain et al. 2009), two (Stb10 and Stb11) are on group 1 chromosomes and one (Stb15) is on a group 6 chromosome. The genes on wheatgrass chromosomes $1 \mathrm{E}$ and $6 \mathrm{E}$ hopefully can augment the STB resistance identified on the same homoeologous groups in wheat. Interestingly, Chinese Spring is thought to contain gene Stb6 (Chartrain et al. 2005), which is located on the short arm of wheat chromosome 3A (Brading et al. 2002). The disomic substitution line $3 \mathrm{E}(3 \mathrm{~A})$ had the highest disease severity and was significantly more susceptible than Chinese Spring in Experiment 1, possibly due to deletion of the Stb6 gene on wheat chromosome 3A. However, this difference was not noted in Experiments 2 and 3 when overall disease pressure was somewhat lower than it was in Experiment 1. The group 4 substitution lines and line $5 \mathrm{E}(5 \mathrm{~B})$ also had significantly higher disease severities compared to Chinese Spring in Experiments 1 and 2. Because not all group 4 and group 5 substitution lines were available, it is not clear whether this higher level of susceptibility to M. graminicola was due to the loss of wheat genes for resistance or the addition of wheatgrass genes for increased susceptibility.

The results of the present work confirmed some of the yellow dwarf resistances identified previously and identified others that may be new. McGuire et al. (1995) analyzed resistance to BYDV in these substitution lines in field plots. Those experiments identified 
a moderate reduction of symptoms in lines $1 \mathrm{E}(1 \mathrm{~A})$, $1 \mathrm{E}(1 \mathrm{D})$, and $2 \mathrm{E}(2 \mathrm{~A})$, with major reductions in $2 \mathrm{E}(2 \mathrm{~B})$, $2 \mathrm{E}(2 \mathrm{D})$, and $5 \mathrm{E}(5 \mathrm{D})$. This study confirmed the resistance in lines $2 \mathrm{E}(2 \mathrm{~B})$ and $2 \mathrm{E}(2 \mathrm{D})$, but did not support the strong resistance on $5 \mathrm{E}(5 \mathrm{D})$, and also found potential new resistance to $\mathrm{BYDV}$ in lines $3 \mathrm{E}(3 \mathrm{~A})$ and $3 \mathrm{E}(3 \mathrm{~B})$.

Resistance to BYDV and CYDV in the present study was measured as a reduction of titer in plants grown in a growth chamber under optimal conditions and co-infected with both viruses. The study by McGuire et al. (1995) defined BYDV resistance by visual symptoms in field-grown plants, which does not distinguish between tolerance and titer reduction. Because the 5E effect was not observed in the current study it is likely that the resistance effect of this chromosome reported by McGuire et al. (1995) was due to genes for tolerance, defined as a reduction in symptom development but not virus titer (Cooper and Jones 1983). Tolerance was not determined in this study because virus titers and not symptoms were quantified. Symptoms were not quantified because plants were grown under optimal environmental conditions that reduce symptom development; adverse environmental conditions are known to influence symptom expression (D'Arcy 1995). Although more research is required to determine whether $5 \mathrm{E}$ confers BYDV/CYDV tolerance or resistance, it is clear from these two studies that the complete resistance contained in L. elongatum is complex with several loci involved across multiple chromosomes.

For CYDV, chromosomes $2 \mathrm{E}$ and $3 \mathrm{E}$ provided excellent resistance, for some lines almost as good as that of the Lophopyrum controls. Possibly useful but weaker resistance was identified in the substitution lines containing wheatgrass chromosomes $6 \mathrm{E}$ and $7 \mathrm{E}$. The CYDV resistance on wheatgrass chromosome $3 \mathrm{E}$ appears to be new. Combining the resistances on $2 \mathrm{E}$ and $3 \mathrm{E}$ might be effective against CYDV in the field, but this remains to be tested.

One unexpected result was that the 7E(7A, 7B, 7D) lines did not provide resistance to BYDV. In previous studies, an alien group 7 chromosome from the hexaploid wheatgrass $L$. intermedium conferred complete resistance to CYDV and a 50\% or greater reduction in BYDV titer in addition or substitution lines (Anderson et al. 1998). In the present work no effect was seen of the 7E chromosome on BYDV. The resistance against CYDV was significantly better than that in Chinese Spring, but not as good as that in $L$. elongatum. These data suggest that BYDV/CYDV resistance varies among wheatgrass species and accessions.

The lack of resistance to powdery mildew in the wheatgrass controls was unexpected because Lophopyrum species grown in our greenhouse typically have not been susceptible to this disease, even when it was present on adjacent plants. The observed susceptible response of Lophopyrum may be due either to the specific Lophopyrum accessions or $B$. graminis strain used or to the ideal growing conditions for this fungus in the humid growth chamber used for the tests. Unfortunately, it was not possible to test the donor parent of the Lophopyrum chromosomes; another possibility is that it may be susceptible to the strain of B. graminis used for the tests, even though other Lophopyrum accessions often appear to be highly resistant.

The disomic substitution lines also lacked resistance to Hessian fly, although $L$. intermedium was scored as resistant. Whether the resistance in $L$. intermedium is broad spectrum and non-host or is due to a specific gene that was not present in the $L$. elongatum donor of the substitution lines is not known. Testing of substitution lines with $L$. intermedium $\mathrm{cv}$. Oahe as the chromosome donor possibly could identify new sources of resistance to Hessian fly.

This set of wheat $\times$ L. elongatum disomic substitution lines provides an excellent genetic resource for studying disease and insect resistance as well as other traits. The systematic analysis of alien chromosomes substituted into the wheat cultivar Chinese Spring identified genes for resistance to M. graminicola on chromosomes $1 \mathrm{E}$ and $6 \mathrm{E}$ and to $\mathrm{CYDV}$ on $2 \mathrm{E}$ and $3 \mathrm{E}$. These lines have the potential to provide new sources engendering significant levels of resistance against these and other important pathogens. Agronomically significant resistance to BYDV, powdery mildew, and Hessian fly was not detected among the individual $L$. elongatum disomic substitution lines. The L. intermedium line was resistant to Hessian fly biotype $\mathrm{L}$ and may, therefore, provide a new source of resistance to this important insect pest. These data also showed that SSRs mapped in wheat have confirmed the chromosome substitution in several lines and may be used as markers for wheatgrass-derived traits.

These analyses only hint at the potential genetic resources present in the various species of 
wheatgrass. Traits in these cytogenetic stocks reflect what was present in a single accession of $L$. elongatum. Other accessions of this species may contain additional resistances that were lacking in the parent of this set of substitution lines. Other useful genes also may be present in closely related wheatgrass species. Variability among accessions could explain the susceptibility to powdery mildew and Hessian fly within this set of substitution lines, even though some wheatgrass accessions appear to be highly resistant. The various species of wheatgrass provide an excellent reservoir of potentially useful traits that should be tapped more widely for cereal improvement in the future.

Acknowledgements The authors wish to thank Jill Breeden, George Buechley, Brett Roberts, and Bryan Wallace for their technical contributions with the disease screening or molecular marker experiments. This work was supported by Purdue University project 3602-22000-014-03S and USDA-ARS CRIS projects 3602-22000-012-00D, 3602-21220-013-00D, and 3602-21220-008-00D. Support for G.G. was provided by the Hungarian-American Fulbright Commission, Grant No. 1201 102.

\section{References}

Adhikari TB, Anderson JM, Goodwin SB (2003) Identification and molecular mapping of a gene in wheat conferring resistance to Mycosphaerella graminicola. Phytopathology $93: 1158-1164$

Anderson JM, Bucholtz D, Greene AE, Francki MG, Gray SM, Sharma H, Ohm HW, Perry KL (1998) Characterization of wheatgrass-derived barley yellow dwarf virus resistance in a wheat alien chromosome substitution line. Phytopathology 88:851-855

Brading PA, Verstappen ECP, Kema GHJ, Brown JKM (2002) A gene-for-gene relationship between wheat and Mycosphaerella graminicola, the Septoria tritici blotch pathogen. Phytopathology 92:439-445

Chartrain L, Brading PA, Brown JKM (2005) Presence of the Stb6 gene for resistance to septoria tritici blotch (Mycosphaerella graminicola) in cultivars used in wheatbreeding programmes worldwide. Plant Pathol 54: 134-143

Chartrain L, Sourdille P, Bernard M, Brown JKM (2009) Identification and location of $S t b 9$, a gene for resistance to septoria tritici blotch in wheat cultivars Courtot and Tonic. Plant Pathol 58:547-555

Cooper JI, Jones AT (1983) Response of plants to viruses: proposal for the use of terms. Phytopathology 73:127-128

D'Arcy CJ (1995) Symptomology and host range of barley yellow dwarf. In: D'Arcy CJ, Burnett PA (eds) Barley yellow dwarf virus: forty years of progress. APS Press, St. Paul MN, pp 9-28
Dubcovsky J, Galvez AF, Dvořák J (1994) Comparison of genetic organization of the early salt stress response gene system in salt-tolerant Lophopyrum elongatum and saltsensitive wheat. Theor Appl Genet 87:957-964

Dvořák J (1980) Homeology between Agropyron elongatum chromosomes and Triticum aestivum chromosomes. Can J Genet Cytol 22:237-259

Dvořák J, Chen KC (1984) Phylogenetic relationships between chromosomes of wheat and chromosome 2E of Elytrigia elongata. Can J Genet Cytol 26:128-132

Dvořák J, Knott DR (1974) Disomic and ditelosomic additions of diploid Agropyron elongatum chromosomes to Triticum aestivum. Can J Genet Cytol 16:399-417

Dvořák J, Knott DR (1997) Homeologous chromatin exchange in a radiation-induced gene transfer. Can J Genet Cytol 19:125-131

Farshadfar E, Sutka J (2003) Multivariate analysis of drought tolerance in wheat substitution lines. J Cereal Res Comm 31:33-40

Forster BP, Reader SM, Forsyth SA, Koebner RMD, Miller TE, Gale MD, Cauderon Y (1987) An assessment of the homoeology of six Agropyron intermedium chromosomes added to wheat. Genet Res 50:91-97

Francki MG, Crasta O, Anderson JM, Sharma H, Ohm HW (1997) Structural organization of an alien Thinopyron intermedium group 7 chromosome in US soft red winter wheat (Triticum aestivum L.). Genome 40:716-722

Friebe B, Jiang J, Raupp WJ, McIntosh RA, Gill BS (1996) Characterization of wheat-alien translocations conferring resistance to diseases and pests: current status. Euphytica 91:59-87

Goodwin SB (2007) Back to basics and beyond: increasing the level of resistance to Septoria tritici blotch in wheat. Australasian Plant Pathol 36:532-538

Jauhar PP, Peterson TS (2000) Toward transferring scab resistance from diploid wild grass, Lophopyrum elongatum, into durum wheat. 2000 National Fusarium Head Blight Forum 201-204

Knott DR (1984) The genetic nature of mutations of the gene for yellow pigment linked to Lr19 in 'Agatha' wheat. Can J Genet Cytol 26:392-393

Liu XM, Brown-Guedira GL, Hatchett JH, Owuoche JO, Chen MS (2005) Genetic characterization and molecular mapping of a Hessian fly-resistance gene transferred from $T$. turgidum ssp. dicoccum to common wheat. Theor Appl Genet 111:1308-1315

Ma J, Zhou R, Dong Y, Jia J (2000) Control and inheritance to yellow rust in Triticum aestivum-Lophopyrum elongatum chromosome substitution lines. Euphytica 111:57-60

McGuire PE, Zhong G-Y, Qualset CO, Dvořák J (1995) Resistance to barley yellow-dwarf-virus disease in derivatives of crosses between hexaploid wheat and species of Lophopyrum (Triticeae, Poaceae). Plant Breed 114: 287-290

McIntosh RA, Hart GE, Devos KM, Gale MD, Rogers WJ (1998) Catalogue of gene symbols for wheat. In: Proceedings of the 9th International Wheat Genetics Symposium. Saskatchewan, Canada

Ratcliffe RH, Ohm HW, Patterson FL, Cambron SE, Safranski GG (1996) Response of resistance genes H9-H19 in wheat to Hessian fly (Diptera: Cecidomyiidae) laboratory 
biotypes and field populations from the eastern United States. J Econ Entom 89:1309-1317

Röder MS, Korzun V, Wendehake K, Plaschke J, Tixier M-H, Leroy P, Ganal MW (1998) A microsatellite map of wheat. Genetics 149:2007-2023

Sardesai N, Nemacheck JA, Subramanyam S, Williams CE (2005) Identification and mapping of $H 32$, a new wheat gene conferring resistance to Hessian fly. Theor Appl Genet 111:1167-1173

SAS Institute Inc. (2004) SAS/STAT ${ }^{\circledR} 9.1$ User's Guide. SAS Institute Inc. Cary, NC, USA

Seo YW, Jang CS, Johnson JW (2001) Development of AFLP and STS markers for identifying wheat-rye translocations possessing 2RL. Euphytica 121:279-287

Sharma HC, Gill BS, Uyemoto JK (1984) High levels of resistance in Agropyron species to barley yellow dwarf and wheat streak mosaic virus. Phytopathologische $\mathrm{Z}$ 110:143-147

Sharma HC, Ohm HW, Lister RW, Foster JE, Shukle RH (1989) Response of wheatgrasses and wheat $\times$ wheatgrass hybrids to barley yellow dwarf virus. Theor Appl Genet 77:369-374

Shen X, Kong L (2004) Ohm H (2004) Fusarium head blight resistance in hexaploid wheat (Triticum aestivum)-Lophopyrum genetic lines and tagging of the alien chromatin by PCR markers. Theor Appl Genet 108:808-813
Shen X, Ohm H (2006) Fusarium head blight resistance derived from Lophopyrum elongatum chromosome 7E and its augmentation with $F h b 1$ in wheat. Plant Breed 125:424-429

Shukle RH, Lampe DJ, Lister RM, Foster JE (1987) Aphid feeding behavior: relationship to barley yellow dwarf virus resistance in Agropyron species. Phytopathology 77:725-729

Tuleen NA, Hart GE (1998) Isolation and characterization of wheat-Elytrigia elongata chromosome $3 \mathrm{E}$ and $5 \mathrm{E}$ addition and substitution lines. Genome 30:519-524

Williams CE, Collier CC, Sardesai N, Ohm HW, Cambron SE (2003) Phenotypic assessment and mapped markers for $H 31$, a new wheat gene conferring resistance to Hessian fly (Diptera: Cecidomyiidae). Theor Appl Genet 107: 1516-1523

Zhang H-B, Dvořák J (1990) Isolation of repeated DNA sequences from Lophopyrum elongatum for detection of Lophopyrum chromatin in wheat genomes. Genome 33: 283-293

Zu-Jun Y, Zheng-Long R (2001) Chromosomal distribution and genetic expression of Lophopyrum elongatum (Host) A. Löve genes for adult plant resistance to stripe rust in wheat background. Genet Resour Crop Ev 48:183-187 